\title{
"A Web of Subversive Friends": New Monasticism in the United States and South Africa
}

\author{
Rachel C. Schneider \\ Religion and Public Life Program, Rice University, 6100 Main St., MS-28, Houston, TX 77005, USA; \\ rachel.c.schneider@rice.edu
}

Received: 8 May 2018; Accepted: 5 June 2018; Published: 7 June 2018

\begin{abstract}
This article analyzes new monastic efforts to engage with systemic inequality in the United States and South Africa, arguing for the importance of the concept of friendship to new monastic social justice efforts. Growing in popularity during the 2000s, new monasticism is a term used to describe Christians who are experimenting with forms of community and subject formation that take as their inspiration earlier monastic or other Christian socialist/communitarian movements. Drawing on qualitative research conducted with two South African groups inspired by new monasticism, I show how building relationships with economic and racial others is central to new monastic visions of social change. New monastics emphasize the importance of deep, committed, authentic, relationships-friendships_-as the primary means of surmounting race and class divides. Building on the insights of Michael Emerson and Christian Smith in Divided by Faith, I argue that how new monastics conceptualize friendship simultaneously draws on and subverts traditional evangelical approaches to social engagement. Although new monastics are similar to evangelicals in that they attach central importance to interpersonal relationships, new monastics are distinct in that they explicitly connect the value of relationship building to practices of self-transformation and social critique.
\end{abstract}

Keywords: new monasticism; Emerging Church Movement; South Africa; United States; poverty; race; inequality; religion; evangelicals

\section{Introduction}

Growing in popularity during the 2000s, new monasticism is a term used to describe Christians who are experimenting with forms of community and subject formation that take as their inspiration earlier monastic or other Christian socialist/communitarian movements. Often identified as part of the larger Emerging Church Movement (ECM), new monasticism represents a "movement of cultural critique" in response to conservative evangelicalism, stagnant mainline denominations, and consumer capitalism (Bielo 2011a, p. 5; Markofski 2015; Marti and Ganiel 2014). For those living in the United States, there is a particular conviction that the American way of life-the American Dream-has produced forms of religion antithetical to the teachings of Jesus (Byassee 2005). Thus, many new monastics understand themselves as living in the midst of "Empire" and called to resist through the creation of alternate lifestyles that value the collective good over individualism as well as the sharing of resources over personal prosperity.

Predominantly white and educated, new monastics view mainline and evangelical Protestant Christian churches as isolating, homogenous, and impersonal; divorced from urgent social concerns; and crassly consumerist (Bielo 2011a, pp. 13-14). By contrast, they strive to embody a more authentic spirituality that appeals to people who are, in the words of American leader Shane Claiborne, "smothered with Christianity, but thirsty for God [ ... ] disenchanted with church; yet still quite fascinated with Jesus of Galilee" (Claiborne 2005, pp. 26-27). This Jesus is seen as one who identifies 
with the poor and who critiques religious elites for their callous indifference to social suffering; the Jesus of the Beatitudes who calls the poor blessed but condemns the rich (Luke 6:20-26).

New monastics believe that, throughout church history, in response to broader cultural crisis or conditions of oppression, groups of committed believers have fled centers of power in order to create alternate forms of life (Rutba House 2005, pp. vii-ix). They cite as inspiration the Desert Fathers and Mothers of the fourth century, Benedictine and Franciscan monastic movements, sixteenth century "radical reformers" such as the Anabaptists, and twentieth century movements such as the Catholic Workers Movement (Rutba House 2005, p. ix). However, unlike traditional monastic communities, new monastics emphasize that there is no one way to be neo-monastic. Instead, communities and individuals must discern for themselves the practices (or "rules") that make sense for them to adopt. What new monastics share with older forms of monasticism, however, is a desire to construct in the words of Alasdair MacIntyre "local forms of community" that provide alternatives to dominant social, political, economic, and religious systems (MacIntyre 2007, p. 263). They often "intentionally establish themselves in places where social needs are evident," immersing themselves in activities that address issues such as homelessness, addiction, incarceration, environmental degradation, and human trafficking (Markofski 2015, p. 2).

Though the term is less invoked in recent years, a wide range of individuals and communities cite as inspiration and/or can be linked to new monasticism. In the United States, new monastic leaders such as Shane Claiborne and Jonathan Wilson-Hartgrove are particularly engaged with questions of economic justice and racial inequality as part of a broader critique of American politics in a post-9/11 world (Dalrymple 2010). They are especially critical of American ideals of upward mobility and theologies of personal prosperity. By contrast, they advocate a communitarian theology that emphasizes the sharing of economic resources.

This article is primarily concerned with the practices and philosophies that inform new monastic efforts to intervene in systems of social inequality both in the United States and South Africa. I am particularly interested in the role that friendship plays in new monasticism. The primary research on which this article is based was conducted in Johannesburg from 2013-2014 and involved qualitative interviews, participant observation, and media analysis. All subjects gave their informed consent, and the protocol was approved by the Institutional Review Board at Rice University (14-051E) on 10 October 2013.

This article begins by describing several models of new monasticism. I then examine several core practices that, while not uniform in application or adoption, are considered central to new monastic efforts to engage with issues of poverty and inequality in the United States and transnationally. While it remains true that many new monastics engage in a "bricoleur fashion, appropriating only selected practices," over time, certain principles have emerged that "mark" new monasticism and allow it to be distinguishable from other forms of Christianity (Bielo 2011a, 99). I then turn to my primary research site of South Africa in order to illustrate new monastic interventions in systemic inequality more concretely. Through two case studies of South African groups inspired by new monasticism, I show how building relationships with economic and racial others is central to new monastic visions of social change. New monastics emphasize the importance of deep, committed, authentic, relationships-friendships_-as the primary means of surmounting race and class divides.

In analyzing new monastic efforts to engage with social inequality in the United States and South Africa, this article builds on previous qualitative research that highlights the importance of authentic relationships to new monasticism and the broader Emerging Church Movement (Bielo 2011a; Markofski 2015; Marti and Ganiel 2014). In my final section, I consider the implications of new monasticism and its emphasis on social subversion through friendship. Building on the insights of Michael Emerson and Christian Smith in Divided by Faith, I argue that new monastics, much like conservative evangelicals, consider the failure to love one's neighbor (a failure of relationship) to be a fundamental cause of racial divisions and economic inequality. Individual behavior, in other words, is seen as a root cause of social dysfunction, which is why new monastics place so much emphasis 
on personal and interpersonal modes of social transformation. At the same time, how new monastics conceptualize friendship simultaneously draws on and subverts traditional evangelical approaches to social engagement. In prioritizing friendship, new monastics exhibit what Emerson and Smith call relationalism; that is, they attach "central importance to interpersonal relationships" (Emerson and Smith 2000, p. 76). However, in contrast to conservative evangelicals, new monastics explicitly connect the value of relationship building to practices of self-transformation and social critique.

Compared to conservative evangelicals who rely heavily on individual explanations and solutions for social inequality, new monastics accept both individual and structural explanations for inequality. This makes them significantly more likely to embrace the need for systemic change, even if they share evangelicalism's preference for grassroots, bottom-up solutions centered on personal and interpersonal transformation. Moreover, new monastic emphasis on forming friendships across lines of difference provides them with strong sense of meaning, belonging, and solidarity. However, it is not always clear whether new monasticism's emphasis on friendship can bring about the large-scale change needed to truly allow for liberation from the bonds of poverty. Further, new monastic practices such as relocation to poor urban neighborhoods can bring threats of voyeurism and gentrification to marginalized communities while reinforcing white privilege. Finally, building relationships in contexts of extreme inequality can be precarious, raising questions about the unintended consequences of relational engagement with poverty and racial inequality.

\section{Models of New Monasticism}

Within the United States, several leaders and communities have emerged as emblematic of the new monastic movement. The most well-known is The Simple Way, an intentional community based in Philadelphia. The community was originally founded in 1998 by students from Eastern University, an evangelical Christian university, who were shaped by a powerful experience of standing in solidarity with homeless families about to be evicted from a Catholic church they had sheltered in. The Simple Way understands themselves as "inspired by the early church in the book of Acts, where early Christians shared all their possessions in common, gave freely to those in need, and met together for worship. The Gospel was lived out of dinner tables and living rooms" (The Simple Way: About n.d.). Similar to other new monastics, they believe that following Jesus requires concrete and long-term engagement with people and places that have tended to be unloved, and they are invested in working to transform their neighborhood, which is economically disadvantaged. They do so primarily through organizing food distribution, emergency services, community gatherings, and education programs. They also participate in social actions that address issues such as racial justice, mass incarceration, violence, and inequalities between rich and poor. Their community is now made up of a dozen properties used to house Simple Way members and serve the wider community.

The Simple Way is also famous because of its founding member Shane Claiborne who has popularized the theo-social vision of new monasticism through his writings. Claiborne's 2006 book The Irresistible Revolution: Living as an Ordinary Radical was reprinted in 2016 and has sold over 300,000 copies. In the book, Claiborne uses his life (and the life of the Simple Way community) as a kind of counter-model to conservative evangelism. Part deconversion narrative, it is also an effort to capture the "experiments" that Christians such as Claiborne have engaged in hopes of offering to the public another "face of evangelical Christianity:" one that does not shy away from issues of poverty, war, racism, and social justice (Claiborne 2016, pp. 14, 21).

Another well-known new monastic community is Rutba House in Durham, North Carolina, founded in 2003 by Jonathan Wilson-Hartgrove and his wife Leah when they were in their early twenties. Both had previously been connected to The Simple Way, and Wilson-Hartgrove has subsequently co-authored books with Claiborne. Rutba House is located in Walltown, a historic black neighborhood in Durham. It is a "hospitality house", meaning that the Wilson-Hartgrove family shares their home with visitors and long-term residents who have fallen on hard times, are transitioning out of homelessness or prison, or have intentionally chosen to join the community. Residents share 
meals together, pray together, do chores together, and contribute financially to a common purse that can be used to meet economic needs. According to Wilson-Hartgrove, this mode of living is meant to subvert the typical charity "hierarchy between helper and helped" because everyone contributes to the maintenance of the household community (Abrams 2017).

In addition to founding Rutba House, Wilson-Hartgrove is credited with the initial gathering in 2004 that coined the phrase "new monasticism" to describe the kinds of communities and practices that were forming among some young evangelicals. Since 2004, Wilson-Hartgrove has gone on to found the School for Conversion, a more programmatic venture that works with churches, Duke Divinity School students, and local residents to reimagine spiritual community outside of traditional church spaces as well intervene in the "neighborhood-to-prison" pipeline in Walltown. The School for Conversion is rooted in Martin Luther King Jr.'s vision of beloved community. It seeks to bring people together across lines of race, class, and power so that they can "unlearn habits of social division." The hope is that, through the work of mutual education and work for social justice, new social relations can emerge between oppressor and oppressed (School for Conversion: About Us n.d.).

Though still prioritizing intentional community living, the existence of organizations such as the School for Conversion demonstrate that a once highly experimental movement has matured into a concrete philosophy and approach, which is increasingly passed on to others through leadership development, mentorship opportunities, and education programs. Many of the principles of new monasticism have found their way into a range of faith-based organizations. One group in the United States that has drawn significantly on new monasticism is Mission Year. Originally founded by Tony Compolo in 1997, Mission Year seeks to create opportunities for youth to be "full time missionaries in neighborhoods around the United States." Under the direction of Shawn Casselberry, the organization describes itself as inviting people ages 18-30 to pursue a lifestyle of "loving God, loving people, and living out faith and justice in the city" (Mission Year I Who We Are n.d.). Mission Year participants are asked to live intentionally together for a year in a poor, urban neighborhood of Houston, Philadelphia or Chicago. Participants live a life of simplicity, spend their time working in local community development projects, and reflect intentionally on dynamics of racial and economic injustice and their own spirituality.

New monasticism has also helped to inspire new orientations to international Christian mission and development: one rooted in a long-term commitment of living alongside the destitute as well as the value of "downward mobility" (Bessenecker 2006). An example of this is what might be termed the urban mission movement. One of the main bodies of this movement is The International Society for Urban Mission (ISUM). Founded in Bangkok in 2012, ISUM convenes training and leadership development summits and publishes a journal known as The New Urban World. This network of Christian "thinkers, activists, and leaders" is deeply concerned with urban poverty and rising economic inequality, especially in the Global South. Critiquing "modern mission and development" for their neglect of urban contexts, particularly slums, they seek through "active reflection, personal solidarity, and creative collaboration" to advance peace and justice in the world's cities (ISUM I International Society for Urban Mission n.d.). Their goal is to make long-term, sustainable impact on systemic inequality through "listening to and amplifying the voices of the urban poor" and the development of pro-poor programs that benefit the local communities that urban missionaries are embedded in (About ISUM I ISUM n.d.). The urban mission movement encourages urban missionaries to relocate to inner city areas, slums, and squatter camps, and it devotes substantial attention to the problem of how missionaries should deal with issues of wealth and economic privilege vis-à-vis poor, urban populations. While they do not downplay Christian motivations, the urban mission movement mostly emphasizes that the lifestyles of its participants, along with a demonstrated commitment to qualitative improvement in urban life is the best form of evangelism and public Christian witness. 


\section{Marks of New Monasticism}

Though highly experimental, a core set of practices have emerged over time that "mark" new monastic communities. This marking is important given that most new monastic communities, while sometimes linked to particular churches or denominations, tend to present themselves as quasi-independent of ecclesial structures. In addition, as Philip Harrold pointed out, the adoption of specific practices is a key way that new monastics reimagine the relationship between the self and the social (Harrold 2010, p. 183). In 2005, Rutba House edited a book of twelve "marks" considered central to the new monastic movement. Of the twelve, four marks illustrate how new monastics imagine themselves as intervening in systemic inequality.

\subsection{Relocation}

First, as already mentioned, new monastics place a great deal of emphasis on relocation away from affluent, suburban spaces, arguing for the need to settle in "areas that have been abandoned or neglected by American society" (Miller 2006), particularly poor urban spaces (Bielo 2011b, 2011c, 2013; Markofski 2015). The practice of relocation, in the words of one proponent, is intended to physically demonstrate one's "conversion and commitment" to a new way of life (McKenna 2005, p. 15). While the practice of relocation is primarily understood by new monastics as residential, relocation can also be understood as any actions that redirect one's time, energy, labor, or resources away from privileged centers of power to the margins.

\subsection{Sharing Economic Resources}

In line with the value of relocation, new monastics also promote living simply and the sharing of economic resources with others to curb personal greed. The practice of sharing resources draws on three streams of biblical inspiration: the first is Jesus's command in the Gospels to love one's neighbor as one's self. The second is the witness of the early Christian community represented in the New Testament (Acts 4), where members shared all things in common and attended to the needy. The third is the Old Testament vision of Jubilee where resources were systematically redistributed between rich and poor on a regular basis. Practices of sharing are also often additionally seen as an act of redistributive justice in response to unjust distributions of wealth and privilege.

\subsection{Reconciliation}

The third mark of new monasticism that addresses economic injustice is lament for racial division and pursuit of just reconciliation, which for new monastics means rejection of racial segregation in ways that transgress the boundaries of middle-class whiteness and promote social justice (Rice 2005). In most cases, practices of reconciliation take on class dimensions due to the racialized nature of poverty and inequality. Once again, their vision of reconciliation draws inspiration from the book of Acts, where individuals reportedly transgressed lines of "language, ethnicity, and privilege" to form a new religious community. It also reflects new monastic dissatisfaction with cultural/racial homogeneity and social insularity (Rice 2005, p. 63).

\subsection{Disciplined Contemplation}

The fourth mark of new monasticism that shapes responses to poverty and inequality is a commitment to a disciplined contemplative life (Wilson-Hartgrove 2005). New monastics highly value authenticity and honest reflection on the conditions of one's life. In addition to emphasizing traditional contemplative spiritual practices such as prayer, solitude, silence, and retreat, this commitment can be construed broadly as critical reflection on one's values and social environment as well as willingness to deconstruct previously accepted religious narratives. Disciplined contemplation, then, involves "unlearning the hidden habits of racism, ethnocentrism, and exclusion," which maintain the very divisions new monastics seek to undermine through their emplacement (Rice 2005, p. 64). 


\subsection{Resisting Empire through Friendship}

The practices described above help illuminate an approach to social inequality that characterizes new monasticism. Through voluntary practices of relocation, redistribution, reconciliation, and critical contemplation, new monasticism aims to make the realities of urban poverty personal to core participants (Marti and Ganiel 2014, p. 151). This is important because new monastics understand poverty and inequality to be primarily a relational problem. According to Claiborne, poverty is not created by God but by humans, because "we have not learned to love our neighbors as ourselves" (Claiborne 2005, p. 31). This failure to love is perceived to be the root cause of inequality, producing social and spiritual distance between rich and poor.

For new monastics, the effects of the relational gap between rich and poor are not only material, but also spiritual. New monastics assert that the rich are spiritually impoverished due to their isolation from the poor because God is found with the oppressed. Thus, new monastic practices are intended to communicate the message that "rather than remaining isolated in safe, suburban pockets of evangelical subculture," one is willing to reject the pressures of individual economic advancement in pursuit of authentic Christianity (Markofski 2015, p. 2). As Claiborne explains, "So many young Christians today were born into a Christendom that lives quite comfortably in a sedate and suburban environment, a Christendom in which they are not really called to sacrifice radically in order to follow Jesus. Yet there seems to be a hunch that Christ calls us to something more than that" (Dalrymple 2010). The quest for radical authenticity—set in opposition to the values of middle class life-defines new monastic spirituality.

A quest for authentic spirituality combined with a desire for meaningful relational bonds with the marginalized leads to the conclusion that the best way to address economic inequality is through personal and interpersonal practices that seek to break down racial and socioeconomic divides. This conclusion is not surprising given the discontent that new monastics often feel with the fragmentation and stresses of capitalist life and their longing for authenticity (Bielo 2011a). Many are attracted to the more communal forms of life found among those on the underside of global capitalism. For this reason, friendship is considered a foundational building block in the creation of alternate social and spiritual communities that encourage interdependence and bridge race and class divides.

\section{From Strangers to Friends}

Having given an overview of different models and practices of new monasticism, in this section, I turn to South Africa to illustrate more concretely new monastic responses to systemic inequality, drawing on interviews and participant observations conducted in 2013-2014 in Johannesburg. I have written previously about the growth and impact of the Emerging Church Movement in South Africa, especially with regards to race (Schneider 2018). New monasticism has been particularly influential in social justice efforts among young, progressive white Christians in South Africa. Similar to the United States, South Africa is a context marked by extreme economic divides that are correlated to race. In what follows, I discuss two examples of individuals who have been shaped by new monastic emphasis on building friendships and community with racial/economic others in ways that transform them from strangers to friends. They have also been inspired by the idea that deep personal engagement with one's neighborhood can be a means of subverting middle-class norms and prompting social change.

\subsection{Becoming Good Friends to Our Neighbors}

The first case I want to discuss is Nigel and Trish Branken, a white South African couple in their forties who started a non-profit organization in inner city Johannesburg called Neighbors. In 2012, the Brankens relocated with their five children from a six-bedroom home in the wealthy suburbs to a three-bedroom apartment in Hillbrow, considered to be the most "dangerous" neighborhood in 
Johannesburg. Formerly a symbol of white cosmopolitanism during apartheid, Hillbrow now houses African migrants from around the continent.

Social workers by training, Nigel and Trish used their institutional knowledge and access to elite networks to try to encourage the voluntary transfer of resources from rich to poor, such as securing legal aid and healthcare from suburban contacts for those around them with limited access. In addition to running an education center and conducting homeless outreach, the Brankens generally worked as ad hoc social workers in Hillbrow, doing everything from monitoring municipal trash pickup to showing up at court to advocate for harassed local political activists or evicted residents.

Similar to other new monastics, the Brankens primarily framed their decision to live and work in Hillbrow in relational terms, arguing that their lifestyle is primarily about becoming "good friends to our neighbors and becoming good neighbors to our friends." More concretely, they aim to become good neighbors and friends to the kinds of people who elite South Africans are most distant from. In Neighbors' mission statement, quoted at length below, new monastic tropes of self-transformation and direct, personal involvement in response to poverty and inequality are clear:

We are a rather ordinary family doing some extraordinary things. We believe as Christians that God is extremely concerned with the brokenness in our city and nation and that He has called each one of us to get involved in making a difference. To bring change, we need to see the future, prepare for the future and then become the future ... or in the words of Ghandi "we must become the change we want to see in the world."

We want to see a world in which the rich do not tolerate extreme poverty and inequality. We want to see many people actually laying down their lives of comfort and convenience for the sake of bettering the lives of others. Seeing people freed from poverty, inequality, racism and exploitation is more important than fulfilling our lust for more things! We want to be part of a society in which people are valued more than things. We want to see the god of consumerism in South Africa bowing it's knee to a love motivated revolution which results in freedom from oppression and exploitation. We want to see this for all people, regardless of class, citizenship, race or religion. We dream of equality in every sector of society. We believe that if the education system is not OK for a rich kid, it is not OK for a poor kid. The same goes with healthcare, housing, security. The same goes for rural kids and inner city kids. The same for black kids and white kids. We are not more valuable than the least valued in our society. We are doing our lives in a new way. We are going to live our dream and see this reality briefly described above happening around us. We hope others will join us and this will happen around them too. Who knows, very soon, the world can be a different place! (Neighbors: About n.d.)

Nigel and Trish understood themselves to be engaged in the work of bridging social divides, not only through development work but also through helping form new relational networks between urban and suburban, rich and poor. They regularly provide opportunities for people in the suburbs to visit and experience Hillbrow. During my fieldwork, the main way that they did this was through a Thursday night soup kitchen event that involved preparing a meal and going out into the streets to share food and pray with local homeless residents (many of whom the Brankens had gotten to know on a personal basis). The event was preceded by a time of reflection and dialogue in the Branken apartment where volunteer participants were encouraged to "become good friends to our neighbors and good neighbors to our friends." Helping wealthy suburbanites begin to reimagine urban residents as friends and neighbors (i.e., human) rather than as amorphous threats was part of how the Brankens saw themselves embodying new monastic value of reconciliation.

Though I never heard the Brankens claim to be new monastics, they cited Shane Claiborne as one of their primary inspirations, and regarded The Irresistible Revolution to be their primary manual next to the Bible (Claiborne 2016). Claiborne's importance to the Brankens and similar groups is perhaps best illustrated by the fact that, during my fieldwork, Claiborne visited Hillbrow, holding a public 
speaking event that many of my interlocutors attended. He also helped lead a workshop for African leaders engaged in urban ministry in places such as Harare, Nairobi, and Cape Town.

Additionally, the fact that the Brankens aspired to build "intentional community" in Hillbrow speaks to the influence of new monasticism on their vision of social change. At the time of my research, this sense of community extended beyond their family to include a small group of interns and regular volunteers, which was comprised of a few black Hillbrow residents, international volunteers, and suburban volunteers.

Similar to other new monastics, the value of relocation was something that the Brankens fully affirmed. I visited them many times in their Hillbrow apartment. Located on the third floor of a relatively well-managed building compared to the surrounding buildings, the flat's limited physical space seemed to miraculously expand to hold a constant flow of visitors, friends, neighbors, and volunteers in addition to their six children. The Brankens also rented two additional flats in their building: one was used to house an education/activity center for neighborhood children. The other housed volunteers, interns, and a four-person Zimbabwean family who assisted the Brankens with their development activities and childcare.

In blog posts on their website and media interviews, the Brankens describe the impact of their relocation journey. On the one hand, their emplacement in Hillbrow has forced them to confront structural injustice in the form of homelessness, migration, poverty, hunger, addiction, and death. On the other hand, they feel liberated from the individualism, consumerism, and rigidity of family life in the suburbs. As their oldest pre-teen daughter happily shared in an interview, "we have lots of friends here and most of them only live a floor up or down. In Midrand, my mom had to drive me to see my friends, and we always had to make appointments. Here, they just pop in (Eaton 2013)". In the initial months after their move, the Brankens marveled at the increased sense of community and purpose they felt. They joyfully report scenes of their children thriving as they make new friends, and they also share discoveries of local arts and music education programs found in the city. They do not focus on what they missed or losses associated with their move. Rather, they describe the relational benefits of a life of increased simplicity.

The Brankens also saw themselves as practicing "solidarity with the residents of Hillbrow and communities deeply impacted by poverty, inequality and injustice around South Africa." An important aspect of practicing solidarity for them was describing and reporting on their personal experiences of navigating inner city life. In line with their understanding of solidarity, they have made the decision to use local public services as often as possible, so that they are not talking simply about or on behalf of the poor and marginalized when they engaged in public advocacy, but instead speaking from their own first-person experience about issues of common concern. For example, the entire family used the local Hillbrow public health clinic for their primary care, which often involved lining up in the early hours of the morning with other neighborhood residents, waiting in long queues to be seen, and adapting themselves to mass-based health practices used by the resource strapped clinic. Such experiences have given the Brankens a great deal of compassion as well as expertise in the bureaucracies and services provided to disadvantaged populations. The Brankens' way of life illustrates how practices of relocation, sharing, reconciliation, and critical reflection-framed around being active members of their community for better and for worse-can result in taking on a certain amount of embodied risk and vulnerability. While personally quite taxing, it did produce a sense of shared experience and destiny with the poor and oppressed.

\subsection{Doing It with My Friends}

The second case study I want to discuss is a nonprofit development organization that I will call RISE. This organization works primarily in a black, mixed-income area outside of Johannesburg. Its core community is composed of a group of young progressive black and white South Africans who seek through their service and way of life to effect change in their communities. The group understands themselves as working to foster a racially inclusive and egalitarian form of community (a "movement") 
through their relationships with one another, with the hope that their community can serve as a model for wider social change. At the time of my fieldwork, most core members were not part of a regular or traditional church. Some even were hesitant to identify as Christian. However, they saw their work as helping reimaging notions of church and viewed Jesus as their primary moral exemplar.

For Nina, a white member in her thirties who I interviewed, the experience of cultivating deep, intimate relationships with fellow RISE members has made a significant difference in terms of solidifying her commitment to the long-term work of engaging with systemic inequality. When Nina began working with RISE, she decided to buy a house in the mixed-income black majority area in which RISE worked, relocating from the wealthy white suburbs. Living in a majority black community as a single white female attracted much scrutiny from local residents and white networks alike, but Nina felt committed to living in her community for the long term. She described her decision to relocation as bringing challenges, frustration, and disappointments but also pleasure as a result of the new relationships she was forming.

Sharing her resources with others had become a central value for Nina: a way for her to deal with inherited wealth and disproportionate access to resources because of her status as a white South African. Nina has shared her home, personal belongings, and car with several neighbors over the years. At the same time, Nina has encountered resistance from white friends and family in response to her relocation. "My family and lots of people were just very worried. And obviously not for it." She confessed to me that one of the most difficult aspects of her choice to live and work in an impoverished black space was "not having a sense of being understood" by white friends and family, many of whom refused to visit her for fear of crime or their safety.

Over time, Nina has been forced to develop various ways of coping with debilitating feelings of anger and sadness in response to white "ignorance." She related, however, that, "in the beginning ... I wasn't that graceful. I would get so angry and despondent, especially because very few people have mixed friendships, they might have mixed friendships but then it is all still economically in the same class. So comments about government, comments about crime and black people, those things are by far the hardest." While this kind of discourse is often reinforced in elite spaces, Nina no longer could participate in such talk with a sense of indifference.

One way Nina has tried to bridge the gap between rich and poor, white and black, is to invite white friends and family to stay at her house. For many white South Africans, any time spent in majority black space is likely to feel uncomfortable and provoke fear and anxiety as black communities are often associated with criminality and seen as absolutely other. As Nina reflected, "that experience for a lot of people is just ... they are so scared, or their husbands don't allow them to come." Nina hopes opening her home and sharing about her work will ultimately help create "spaces of integration." However, where integration does not happen voluntarily, she often will create it by bringing one of her black colleagues with her to white social gatherings "because then it just makes everyone uncomfortable. You can't talk the same way you do because it is just different." It was unclear to me what black RISE members thought of this kind of strategy. In our conversations, they seemed to recognize the utility and power that came of disrupting white elite spaces but were also ambivalent about the emotional toll navigating such spaces exacted. Additionally, there is always the danger of being reduced from a friend to a moral object lesson.

While her relocation was initially difficult, over time Nina has come to enjoy the subversive possibilities made possible by her life and work. Relationships with black friends and colleagues has brought deeper awareness of racial, cultural, and economic difference along with insight into systemic privilege and injustice. It has also created moments of play and unexpected humor that Nina experienced as immensely pleasurable. "In the beginning it was very hilarious. People are like 'are you buying a house for your maid?' I'm like, no, it is all me. And still if I open the door, the surprise on the faces, it doesn't get old for me, I love it." She particularly enjoyed helping create scenes of symbolic reversal that relied on problematizing social expectations about race and class: 
So when we are at a shop, when we are at a coffee place, let's say, every now and then I would take some of my [black] friends or staff members out for coffee and I would usually pay because I have more money, but what I would do is I give my card to one of them. And then they know my pin, and it is so obvious, like, when the waiter comes, I always get asked first what I want. [ ... ] or we would go into the restaurant, and first I would ask the person I am with, and they [the host] would come and ask me 'Hi maam, where do you want to sit?' and then I just look at the person next to me, and I always let them guide the process and make decisions. So then already ... It's a small thing but it makes a statement, and then if they pay with a card, even if it is my card, we don't show that it is my card, but they pay, and it's like ... it breaks down something, you know?

When asked if her black friends enjoy participating in these kinds of reversals, Nina responded "Absolutely! They are even worse than me." Nina related how a black colleague intentionally plays up the tension whenever he senses hostility or discomfort from others.

Staging moments of subversion with fellow RISE members has created for Nina "endless education" about dynamics of privilege, but perhaps what mattered the most to her was how during such moments "we are all in on it together, which makes it a lot of fun." Indeed, I observed many moments where black and white RISE members seemed to relish the opportunity to subvert social norms tied to race and class in a spirit of comradery. For Nina, the sense of solidarity with black friends, forged through working together against entrenched systems of inequality, provided her with a deep sense of meaning and belonging. Despite the emotional discomfort of relocation, what sustained Nina was the sense that she is doing the work of social transformation "with my friends," and that they are in it together for the "long haul." The sense of community that Nina formed with her RISE colleagues allowed her to feel hopeful about social change amid so much daily suffering.

\section{The Politics of Friendship}

As already noted, many new monastic practices are oriented towards making social inequality personal to those who come from middle-class or affluent backgrounds. However, making poverty personal is not an end in itself. Rather, developing intimate knowledge of economic disadvantage works as a key technology of the self as well as a technology of social transformation (Foucault 1997). The intentional building of meaningful relationships through practices such as relocation and redistribution is seen as a means of moving beyond the rigidity of (white) middle-class life as well as contributing to social justice more broadly.

For new monastics, direct exposure to the undersides of consumer capitalism not only promotes critical reflection, it also creates a shared knowledge base through which to build bonds of communal solidarity with marginalized communities. Such practices, according to Marti and Ganiel, can be viewed as political: "By political, we mean that some people in these communities are committed to living, as far as possible, outside the structures of consumer capitalism in an attempt to subvert them. They see this as emulating Jesus, who they conceptualize as a political activist who worked (nonviolently) outside of the structures of the Roman Empire, ultimately subverting them" (Marti and Ganiel 2014, p. 149). Not only is living alongside the oppressed and forming friendships with them understood to be as an act of solidarity in opposition to dominant systems of power, it also acts as a foil to conservative white evangelicalism, new monasticism's favored point of comparison.

\subsection{Not Quite Evangelical}

Emphasis on authentic community is something most scholars have noted about both the Emerging Church Movement and new monasticism, which they link to the initial influence of American evangelicalism on the movement. Key leaders in new monasticism such as Claiborne and Wilson-Hartgove come from conservative evangelical backgrounds, and many new monastics frame their lifestyle as a rejection of suburban evangelical life. At the same time, one finds a great deal of affinity between the values, ideals, and practices of new monasticism and earlier efforts by 
progressive American evangelicals to engage with racialized poverty and social inequality, including intentional community living in the late 1960s and 1970s as well as political action and public policy work in the 1990s. In many cases, there are direct mentorship and leadership links between new monasticism and progressive evangelicals. For example, Mission Year was originally part of progressive evangelical Tony Compolo's mission organization, and Shane Claiborne has served on the board of Sojourners, an organization headed by Jim Wallis, another prominent progressive evangelical. In addition, Claiborne has served on the board of the Christian Community Development Organization, founded by black evangelical civil rights leader John Perkins, a pioneer in the racial reconciliation and Christian community development movements. Johnathan Wilson-Hartgrove currently has a high-profile partnership with Rev. William Barber III, a black Christian leader in North Carolina famous for organizing the Moral Mondays Movement (Wootson 2017).

The historical roots of American evangelical social engagement are important for understanding how new monastics frame their own approaches to issues of poverty and inequality. In his book Jesus E Justice: Evangelicals, Race, and American Politics, Peter Goodwin Heltzel outlines a shift in American evangelicalism in the 1950s that subsequently sparked both conservative initiatives such as Focus on the Family and progressive initiatives such as Sojourners. Owing to the influence of prominent leaders such as Carl Henry, post-war evangelicals sought to move away from the isolationism and stigma of fundamentalism. Henry, in particular, promoted a broadly Calvinist vision that saw Christian mission as involving more than simply evangelism. Christians were called to engage in voluntary efforts to transform or redeem society and culture, which required active participation in the public sphere (Heltzel 2014, pp. 74-75). At the same time, Heltzel points out, Henry's vision also contained a deep suspicion of the state and government and pessimism about the ability of social programs, such as welfare or affirmative action, to transform problems rooted in human sinfulness. Rather, social transformation must be rooted in personal piety (Heltzel 2014, pp. 76-77).

Evangelical suspicion of social programs and government, combined with an emphasis on free will, is highly significant when considering new monastic approaches to poverty, inequality, and social transformation. In their landmark study of conservative Protestants, Divided by Faith: Evangelical Religion and the Problem of Race in America, sociologists Michael Emerson and Christian Smith cite several religio-cultural aspects of white evangelicalism that work against tackling racialized inequality. They point out that evangelical emphases on "family relationships, friendships, church relationships, and other forms of interpersonal connection," lead to viewing social problems as rooted in "poor relationships" rather than systemic discrimination and structural inequality (Emerson and Smith 2000, p. 78). Many of their respondents (in ways reminiscent of contemporary new monastics) cite the failure to love one's neighbors (a failure of relationship) as fundamentally to blame for racial divisions and inequality. In this way, individual sin is seen as the root cause of dysfunction rather than social structures (Emerson and Smith 2000, p. 78). Combined with a suspicion of government and institutions, Emerson and Smith conclude that these characteristics make it difficult for evangelicals to come to terms with the kind of large-scale structural changes and material sacrifices necessary to address racialized inequality (Emerson and Smith 2000, pp. 130-32).

How do new monastics fare against Emerson and Smith's critique of evangelicals? Generally, new monastics share with evangelicals a deep suspicion about government and institutions. While such attitudes are quite common to progressive activists, new monastics maintain the evangelical belief that individuals need to experience deep transformation, or conversion, if there is to ever be lasting social change. However, new monastics radicalize this belief in that they understand conversion to result in a total lifestyle change, which results not just in individual but communal transformation. New monastics assert that their distinctive way of life is about modeling an alternate economic, social, political and religious system—the Kingdom of God-which can never be reduced to a particular form of government. A lifestyle rooted in simplicity, service, and downward mobility is envisioned as a form of resistance to an oppressive state as well as "the evil that makes capitalism the cause of ever increasing suffering for the poor" (McKenna 2005, p. 22). Circumventing corrupt, 
impersonal institutions, new monastics insist on direct, personal engagement with issues of poverty and marginalization. At the same time, moving beyond a narrow evangelical focus on evangelism and personal piety, new monastics insist that the Kingdom of God must be reflected through social and communal structures that prioritize the poor. For these reasons, they see themselves as engaged in prophetic critique of social evils such as racism, militarism, and consumer capitalism, and they are not afraid to politically mobilize or act in the public sphere as a means of addressing these issues.

New monastics share with evangelicals a form of "engaged orthodoxy" (Emerson and Smith 2000, p. 3; Elisha 2011). That is, they want their faith to offer solutions to pressing social problems. Their preferred methods for addressing poverty and inequality remain rooted in the evangelical belief that personal virtue and authentic relationships are the best way to disrupt the status quo (Elisha 2011). However, new monastics are more likely than evangelicals to be invested in doing the "hard work of social analysis" (Rice 2005, p. 61). While recognizing the need for structural change in response to inequality (something conservative evangelicals are loath to do), they nevertheless retain a form of anti-statism (resisting Empire) that prioritizes individual, voluntary action rather than prescribed programs (Hamilton 2018). Consider how Claiborne frames wealth redistribution: "redistribution is not a prescription ... redistribution is what happens when people fall in love with each other across class lines." It is not "systematically regimented" but rather flows naturally "out of love of God and neighbor," which he argues will ultimately make state-driven systems of both capitalism and communism irrelevant (Claiborne 2005, p. 30).

Indeed, those I interviewed in South Africa shared Claiborne's emphasis on voluntary action. While members of RISE and Neighbors did see a role for the state in advancing social justice, they nevertheless emphasized the voluntary conversion of (white) conscience-a "love motivated revolution" where people lay "down their lives of comfort and convenience for the sake of bettering the lives of others" - rather than state imposed wealth redistribution policies, which some feared might bring violence (Neighbors: About n.d.).This observation is not a critique of new monastics per se. Certainly, for the Brankens, being good friends to their neighbors meant engaging in activities such as political protest, social advocacy, and community development work. However, it is a recognition that new monastics prioritize personal/interpersonal interventions in systemic inequality over top-down bureaucratic approaches. In the words of McKenna, a contributor to The 12 Marks of New Monasticism, new monastic practices are intentionally "personalist" rather than "institutional." Personal practices, such as relocation and the sharing of resources, are understood to lead to greater social solidarity while also helping to inspire collective transformation. McKenna writes, "Hospitality in the form of sharing food, roof, and friendship with neighbors will foster both compassion and engagement and will be a form of holy communion with marginal cultures and poor populations"(McKenna 2005, pp. 1-22). Implicit here is an understanding that relational approaches to intervening in economic inequality will ultimately be more effective than institutional approaches. ${ }^{1}$ Justice and generosity will flow naturally out of one's religious commitments, resulting in the creation of new forms of community where resources are voluntarily shared in an equitable manner and the dignity of all is recognized.

While not opposed to macro-level change, individual lifestyle change ("we must become the change we want to see in the world") and communal change remain the primary focus of new monastics (Neighbors: About n.d.). For new monastics, the fundamental problem continues to be that wealthy Christians contribute to systemic inequalities because they are socially isolated and physically distanced from the lives of the poor. In the words of Claiborne, "the great tragedy in the church is

1 To be sure, new monastics share with both white progressive evangelicals and black Protestants a desire to see broader institutional, legal, and structural transformation in relation to inequality. Much more than conservative evangelicals, they are inclined to see the state as a potential force for social good, even while they remain critical of how the state upholds (white racial) capitalism. This orientation distinguishes them from conservative American evangelicals who tend to strongly reject macro-level or state intervention in systemic inequality. Jonathan Wilson-Hartgrove's participation in the Moral Monday movement or Shane Claiborne's frequent partnership with Sojourners are good examples of how new monastics can seek to influence public policy through political action. 
not that rich Christians do not care about the poor, but that rich Christians do not know the poor" and that "layers of insulation separate the rich and the poor from truly encountering one another" (Claiborne 2005, p. 28). The kinds of things that Claiborne targets as problematic include picket fences, SUVs, "charity" projects, and mission trips, all of which he says "function as outlets that allow us to appease our consciences and still retain a safe distance from the poor"(Claiborne 2005, p. 28). Claiborne laments the ways that Christian missions and charity projects have failed to produce a sense of mutual responsibility and care between the rich and the poor in line with the early Christian community modeled in the book of Acts (Claiborne 2005, p. 29).

\subsection{Making Poverty Personal: Possibilities and Pitfalls}

In their book, Emerson and Smith discuss a fundamental problem tied to evangelical preference for individual-level, relational solutions: "the massive extent of residential, congregational, and other forms of segregation and inequality (all of which are structurally maintained) continually mitigates against the successful formation of friendships and precludes the opportunity of enough people ever forming enough friendships to make a difference"(Emerson and Smith 2000, p. 131). Despite adopting a more expansive and socially-engaged conception of friendship, new monasticism remains equally vulnerable to the dynamics Emerson and Smith identify. It remains unclear whether new monastic efforts at individual and collective transformation can bring about the large-scale change needed to truly allow for liberation from the bonds of poverty. On the other hand, this does not seem to really be the point of new monastic engagements with wealth, poverty, and inequality. Rather, they hope to show in a microcosm a form of life rooted in Christian ethical commitments that rejects the consumer capitalism of Empire and allows for new social possibilities between rich and poor. If they can make a difference in a few lives_or a neighborhood — through the formation of friendships, that is enough.

While it may be tempting to dismiss new monastic approaches to poverty and inequality as marginal due to the small-scale nature of their actions, the significance of their actions emerges when considering them alongside conservative white evangelicals. Emerson and Smith find that a significant barrier to evangelical Christian congregations becoming more socially engaged and racially (and economically) diverse is that increased social engagement produces increased complexity, which tends to decrease a sense of meaning, belonging, and security for individual participants, leading to fragmentation, a sense of alienation, and eventually dissolution (Emerson and Smith 2000, pp. 141-50). I observed these dynamics often among my South African interlocuters. The more socially engaged they became, the more they struggled with a sense of alienation and fragmentation, which in some case led to burn out and withdrawal. However, it is also clear, as evidenced by Nina's case, that new monasticism's strong emphasis on friendship, neighborliness, and interpersonal bonds-being committed for the long term to a particular place and people-helps mitigate the costs of increased diversity by encouraging a strong sense of shared meaning and belonging among participants. This strong sense of social solidarity ("doing it with my friends") ultimately allows for more radical social analysis and inclusion of diversity than can be found in typical evangelical spaces (Emerson and Smith 2000, p. 143).

In addition, new monastic practices of relocation help address another problem. Emerson and Smith find that in order for wealthy, white evangelicals to adopt a less individualistic and more structural explanation of inequality, there needs to be "extensive and extended intergroup contact" that moves beyond a few sporadic friendships to wider social networks where reciprocal exchange, learning, and mentorship can take place (Emerson and Smith 2000, pp. 84, 107). Here, new monastic practices of relocation and sharing of resources come into play. In the words of Rutba House leaders, "it is our neighbors who ground the Rutba House and help us remember who we are." Regular interactions with poor neighborhood residents over time has led Rutba House members, especially those who come from white privileged backgrounds, to begin to envision a shared destiny with those around them: "We are formed by these people, our neighbors, they have become part of us and we have become part of them-our stories are bound together. Sharing life with them has changed how 
we think about the future and how we reflect on the past," allowing for critical reflection on how one's economic habits and choices impact the lives of others in a concrete way (Rutba House 2005, p. vii). This reflection corroborates Emerson and Smith's findings that, when evangelicals live in communities where they are the racial/economic minority, they begin to focus more on communal and justice-oriented religious themes, such as the year of Jubilee, and structural explanations for poverty begin to emerge (Emerson and Smith 2000, p. 108)

Importantly, Emerson and Smith suggest that cross-racial friendship can be a significant factor in shifting white American attitudes towards government intervention on issues of equal housing, employment, and education, but only when whites have a black friend of equal or higher socioeconomic status. Given how rare this is in both American and South African life, there is something to be said for new monastic embrace of downward mobility and redistribution as a means of creating the "conditions of relative integration and socioeconomic equality" necessary for cross-racial friendships to play a socially significant role in shifting "beliefs, feelings, social dispositions, and policy views" (Emerson and Smith 2000, p. 131). I find it significant that white members of RISE and Neighbors seemed willing to absorb relative cultural and financial sacrifice for the sake of bettering the lives of their friends and neighbors, even if at times this was more an ideal than reality.

At the same time, building relationships across social divides is often extremely difficult, given power differentials and histories of injustice. Indeed, I often wondered if the reason that RISE and Neighbors struggled to recruit more black members into their core communities had to do with differences in their lived experiences of poverty coupled with centuries of mistrust. In the United States and South Africa alike, those attracted to new monasticism tend to be white, middle-class, and educated. They are highly attracted to the message that authentic Christianity requires service, sacrifice, downward mobility, and identification with the poor. Conversely, for most people of color, poverty is not something voluntarily chosen but often imposed by broader social structures. Rarely is poverty seen by others as an expression of virtue. The point here is that it takes a certain amount of privilege or a pre-existing safety net to adopt the new monastic way of life, and the perceived social/spiritual value of downward mobility may not be as appealing to people of color who lack these things. As Jason Byassee aptly notes in his article, "perhaps those who have had less of a chance at pursuing the American dream are not yet ready to be disenchanted with it" (Byassee 2005).

Finally, it is crucial to emphasize that forming close personal relationships with racial and economic others brings with it the risk of being charged with exploiting them for personal (or spiritual) gain. Decades ago, black South African activist Steve Biko argued that an emphasis on interracial relationships by white "do-gooders" could all too easily serve as a prop for white egos rather than a tool of genuine social transformation (Biko 2006). While new monastics intentionally seek to work against a white savior complex-instead promoting relationships or mutuality and reciprocity-despite their best intentions, practices such as relocation can serve to reproduce the very systems they seek to resist and dismantle. New monasticism has often been compared to a type of colonialism (Bielo 2011a, pp. 132-37; Rah 2009). Indeed, the threat of new monastic communities contributing to dynamics of gentrification is something that Jonathan Wilson-Hartgrove frankly acknowledges in a recent interview. When the interviewer comments how much Walltown has changed since Rutba House began, Wilson-Hartgrove responds, "Yes, and I have to acknowledge the role we have played in that, which I think also gives our neighbors some suspicion. [ . . ] One of the reasons we didn't add a third house was because almost everybody coming to Rutba House from outside Walltown was white, and we didn't want to establish a 'colony' within the neighborhood. Even so, dozens of people who originally came here to be part of Rutba House have stayed and bought homes in Walltown," which contributes to rising land values (Abrams 2017). The threat of gentrification is likely more of an issue in the United States than in places such as South Africa where the wealthy remain a demographic minority, but the danger of reinforcing colonial logics, such as voyeurism, through relocation to marginalized areas remains present in both contexts. 


\section{Conclusions}

Friendships-deep, committed, personal, authentic relationships-are considered by new monastics to be central to the creation of alternate social and spiritual communities that bridge race and class divides. New monastics believe that those who are privileged contribute to systemic inequality because they are isolated and distanced from the lives of the poor. In their view, the formation of meaningful relationships across lines of social difference work to combat the breakdown in social fabrics that reinforce poverty.

The cultivation of close interpersonal bonds is central to new monasticism, both in the United States as well as transnationally. By claiming the poor as friends-and even family- new monastics publicly affirm that poor lives are just as valuable and meaningful as rich lives. Indeed, it is striking how many groups associated with new monasticism emphasize the formation of friendship and close interpersonal bonds as central to the work of social justice, the means by which participants to begin to love their neighbors as themselves. For example, on Twitter, the Simple Way describe themselves this way: "We are a web of subversive friends, conspiring to spread the vision of Loving God, Loving People, and Following Jesus in our neighborhoods and in our world" (Twitter.com/thesimpleway n.d.). This framing underscores how central friendship is to new monastic spiritual imaginations. Friendship is also a key ingredient of the School for Conversion's mission of building beloved community across lines of social division: "We strive to create spaces where 'surprising friendship' can happen, and we believe these relationships can convert people to a new way of living together and being in the world" (School for Conversion: Home n.d.). In both instances, friendship is understood as the glue that holds the work of social transformation together. Friendship is the means by which strangers become neighbors and learn to live together. The emphasis on friendships across lines of difference speaks to the fact that new monastics fundamentally understand social transformation to be rooted in processes of self-transformation and communal change. The flip side of this vision is the perception that systemic inequality contributes to a "breakdown of community" (Community Education n.d.). Such breakdown, which is reinforced by spatial segregation, allows for the wealthy to lose sight of the common good and depersonalized the poor (Claiborne 2005, p. 29).

While perhaps reducing the territorial stigma of economically neglected areas, new monastic encouragement of relocation tends to raise significant questions about power and accountability once friendships are formed. In true self-reflexive fashion, new monastics themselves tend to recognize that friendship across lines of social difference remains fragile due to external forces and implicit bias. One South African new monastic confessed to me that he had yet to form a true "friendship" across race and class lines, and another told me that a friendship with a local poor, black resident in her neighborhood had collapsed due to wider community suspicion, which in turn caused her to reflect deeply on the social significance of her race/class. All of this showcases how new monastics take the familiar evangelical trope of relationship-building and push it beyond its typically individualized application to engage in radical critique. Friendship, then, emerges as a technology through which new monastics are spurred to deeper social analysis and action. Once poverty and inequality become personal, the personal becomes political.

Conflicts of Interest: The author declares no conflict of interest.

\section{References}

About ISUM I ISUM. n.d. Available online: http:/ / newurbanworld.org/about/ (accessed on 19 February 2017). Abrams, Amanda. 2017. Love Thy Neighbor: Jonathan Wilson-Hartgrove on Race, Faith, and Resistance. The Sun Magazine. Available online: https:/ / www.thesunmagazine.org/issues/501/love-thy-neighbor (accessed on September 2017).

Bessenecker, Scott A. 2006. The New Friars: The Emerging Movement Serving the World's Poor. Downers Grove: InterVarsity Press. 
Bielo, James S. 2011a. Emerging Evangelicals: Faith, Modernity, and the Desire for Authenticity. New York: New York University Press.

Bielo, James S. 2011b. Purity, Danger, and Redemption: Notes on Urban Missional Evangelicals. American Ethnologist 38: 267-80. [CrossRef]

Bielo, James S. 2011c. City of Man, City of God: The Re-Urbanization of American Evangelicals. City E Society 23: $2-23$.

Bielo, James S. 2013. Urban Christianities: Place-Making in Late Modernity. Religion 43: 301-11. [CrossRef]

Biko, Steve. 2006. Black Souls in White Skins? In I Write What I Like. Edited by Aelred Stubbs. Johannesburg: Picador Africa, pp. 20-28.

Byassee, Jason. 2005. Alternative Christian Communities. The Christian Century, October 15.

Claiborne, Shane. 2005. Mark 2: Sharing Economic Resources with Fellow Community Members and the Needy Among Us. In School(s) for Conversion: 12 Marks of a New Monasticism. Edited by Rutba House. Eugene: Wipf and Stock Publishers, pp. 26-38.

Claiborne, Shane. 2016. The Irresistible Revolution: Living as an Ordinary Radical. Grand Rapids: Zondervan.

Community Education. n.d. School for Conversion. Available online: https:/ / www.schoolforconversion.org/ community-education/ (accessed on 1 November 2017).

Dalrymple, Timothy. 2010. How to Derail the New Monasticism: An Interview with Shane Claiborne. Available online: http:/ / www.patheos.com/resources/additional-resources/2010/08/how-to-derail-thenew-monasticism-an-interview-with-shane-claiborne (accessed on 9 August 2010).

Eaton, Jessica. 2013. Hope in Hillbrow: 'If Jesus Lived Anywhere, It Would Be Here' I Daily Maverick. Daily Maverick. Available online: https:/ / www.dailymaverick.co.za/article/2013-07-16-hope-in-hillbrow-if-jesuslived-anywhere-it-would-be-here/\#.WKyip_krI2w (accessed on 16 July 2013).

Elisha, Omri. 2011. Moral Ambition: Mobilization and Social Outreach in Evangelical Megachurches. Berkeley: University of California Press.

Emerson, Michael O., and Christian Smith. 2000. Divided by Faith: Evangelical Religion and the Problem of Race in America. Oxford: Oxford University Press.

Foucault, Michel. 1997. Technologies of the Self. In Ethics: Subjectivity and Truth. Edited by Paul Rabinow. New York: New Press, pp. 223-51.

Hamilton, Michael S. 2018. A Strange Love? Or: How White Evangelicals Learned to Stop Worrying and Love the Donald. In Evangelicalism, Its History, and Its Current Crisis. Edited by David Bebbington, George Marsden and Mark Noll. Grand Rapids: William B. Eerdmans Pub. Co., forthcoming.

Harrold, Philip. 2010. The 'New Monasticism' as Ancient-Future Belonging. Theology Today 67: 182-93. [CrossRef]

Heltzel, Peter. 2014. Jesus and Justice: Evangelicals, Race, and American Politics. City of New Haven: Yale University Press.

ISUM I International Society for Urban Mission. n.d. Available online: http://newurbanworld.org/ (accessed on 1 March 2017).

MacIntyre, Alasdair C. 2007. After Virtue: A Study in Moral Theory. Notre Dame: University of Notre Dame Press.

Markofski, Wes. 2015. New Monasticism and the Transformation of American Evangelicalism. New York: Oxford University Press.

Marti, Gerardo, and Gladys Ganiel. 2014. The Deconstructed Church: Understanding Emerging Christianity. Oxford: Oxford University Press.

McKenna, Margaret M., Sr. 2005. Mark 1: Relocation to Abandoned Places of Empire. In School(s) for Conversion: 12 Marks of a New Monasticism. Edited by Rutba House. Eugene: Wipf and Stock Publishers, pp. 10-25.

Miller, David Ian. 2006. FINDING MY RELIGION/Meet the New Monastics. SFGate. Available online: http: / / www.sfgate.com/news/article/FINDING-MY-RELIGION-Meet-the-New-Monastics-3302587.php (accessed on 13 March 2006).

Mission Year I Who We Are. n.d. Mission Year. Available online: https:/ /www.missionyear.org/who-we-are/ (accessed on 2 May 2018).

Neighbors: About. Neighbours. Available online: http:/ / www.neighbours.org.za/about.html (accessed on 19 February 2017).

Rah, Soong-Chan. 2009. The Next Evangelicalism: Freeing the Church from Western Cultural Captivity. Downers Grove: InterVarsity Press. 
Rice, Chris. 2005. Mark 4: Lament for Racial Divisions Within the Church and Our Communities Combined with the Active Pursuit of a Just Reconciliation. In School(s) for Conversion: 12 Marks of a New Monasticism. Edited by Rutba House. Eugene: Wipf and Stock Publishers, pp. 55-67.

Rutba, House, ed. 2005. School(s) for Conversion: 12 Marks of a New Monasticism. Eugene: Wipf and Stock Publishers. Schneider, Rachel C. 2018. Race and the Emerging Church: A View From South Africa. In The Emerging Church, Millennials, and Religion. Edited by Randall W. Reed. Eugene: Wipf \& Stock, vol. 1.

School for Conversion: About Us. n.d. School for Conversion. Available online: https: / / www.schoolforconversion. org/about-us/ (accessed on 2 May 2018).

School for Conversion: Home. n.d. School for Conversion. Available online: https:/ /www.schoolforconversion. org/ (accessed on 3 May 2018).

The Simple Way: About. n.d. The Simple Way. Available online: http:/ /www.thesimpleway.org/about/ (accessed on 3 March 2017).

Twitter.com/thesimpleway. n.d. Available online: https:/ / twitter.com/thesimpleway (accessed on 3 May 2018). Wilson-Hartgrove, Johnathan. 2005. Mark 12: Commitment to a Disciplined Contemplative Life. In School(s) for Conversion: 12 Marks of a New Monasticism. Edited by Rutba House. Eugene: Wipf and Stock Publishers, pp. 162-72.

Wootson, Cleve R., Jr. 2017. Rev. William Barber Builds a Moral Movement. Sect. Acts of Faith. Washington Post. Available online: https://www.washingtonpost.com/news/acts-of-faith/wp/2017/06/29/woe-untothose-who-legislate-evil-rev-william-barber-builds-a-moral-movement/ (accessed on 29 June 2017).

(C) 2018 by the author. Licensee MDPI, Basel, Switzerland. This article is an open access article distributed under the terms and conditions of the Creative Commons Attribution (CC BY) license (http:/ / creativecommons.org/licenses/by/4.0/). 